of which are to be obtained from H.M. Stationery Office, should, if used generally at schools, put young students on very familiar terms with the weather maps appearing in many of the leading newspapers, and at the same time give some idea of the methods of working of the official forecasters.

\section{Atlantic Ice}

THE work of the United States ice patrol on the Atlantic shipping routes during 1931 (International Ice Observation and Ice Patrol Service, 1931. Coast Guard Bulletin, No. 21) records a most unusual year. The normal number of icebergs coming south of lat. $48^{\circ} \mathrm{N}$. during the year is 419 ; this is the mean of thirty-two year's records. During 1931 only 13 icebergs came so far south and ten of these were in May, which is the month of widest spread ice distribution on the Grand Banks. March showed two bergs and April one south of the 48th parallel. There is only ono record of another year so free from ice-in 1924 only eleven bergs were recorded. These figures may be contrasted with more than a thousand in 1929, 1912, and 1909. The report contains the usual chart of the distribution of ice on the routes frequented by shipping and also the records of oceanographical observations. An interesting appendix gives an account of the ice observations made in the polar seas during the cruise of the Graf Zeppelin in July 1931 over the Barents and Kara Seas.

\section{The North-East Passage}

RUSSIAN newspapers have announced that an expedition on the ice-breaker Sibirjakov, under the leadership of Prof. Schmidt, has succeeded in navi. gating the whole length of the North-East Passage, from the White Sea to Vladivostok. The most dangerous section was found near the North Land, which the expedition rounded on the northern side, where it was necessary to blow up the ice in order .o make any progress. The mouth of the Lena was seached in less than $₫$ month after leaving Arch. angelsk, but great difficulties were encountered between the mouth of Kolyma and the Bering Strait. Here the ice was three to four metres thick and all the blades of the ship's screw were broken one after another. After six days of strenuous work the ship's stern was raised above water by shifting the coal and the necessary repairs mado, but when the expedition was only ninety kilometres from the Bering Strait, the screw was lost altogether, since the main axle broke, so that the remainder of the journey had to be made under sail.

\section{Memorial to Dr. R. Stenhouse Williams}

THE National Institute for Research in Dairying. University of Reading, has recently issued an appeal for funds to provide an appropriate memorial to the late Dr. R. Stenhouse Williams, first director of the Institute, who died on February 2, 1932. It has been decided to devote the fund chiefly to the further development of the Institute. to which Dr. Williams devoted all his energies. The signatories to the appeal, who represent dairy science in all its aspects, consider that this application of the fund will form a lasting monument to Dr. Stenhouse Williams. A small permanent memorial will also be erected within the Institute. Further information can be obtained from Mr. S. R. Whitley, "Rookwood", Shinfield, Reading.

\section{Santos Dumont}

ON December 21, the State funeral of Santos Dumont, the Brazilian pioneer of aviation, took place in Rio Janeiro. His death occurred on July 23 at Sào Paulo, and owing to the disturbed stato of the country he was first interred there. On December 18. after the body had lain in state in the crypt of the Cathedral of Sao Paulo for some time, it was removed to the capital, where on arrival it was met by an escort of military and naval aircraft which performed evolutions during the transit from the station to the Cathedral of Rio Janeiro. The public were afterwards admitted to pay their last respects to one who is proclaimed by his country as the father of aviation, and on December 21 the final rites took place at the St. John the Baptist cemetery.

\section{Announcements}

Mr. H. T. Trzard, Rector of the Imperial College of Science and Technology, has been appointed chair man of the Aeronautical Research Committee in succession to Sir Richard Glazebrook.

THE Government of Ecuador has awarded the decoration of Al Morito, in the degree of Gran Oficial, to Dr. George Sheppard, State geologist to the Republic of Ecuador, in recognition of his valuable work in a consulting capacity to various depart. ments of the Govemment, and also in appreciation of his published contributions to geological science during the past few years.

The annual report of the Rockefeller Foundation for 1931 details the activities of the Foundation, of its grants in aid in various domains of human knowledge, scientific and humanistic, with brief reviews of the chief researches carried out under its endowment. Much work has been done on yellow fever, including trials of preventive vaccination. Under malaria, the existence of two races of Anopheles maculipennis, the chief mosquito-carrier in southern Europe, is described, one with barred, the other with dappled eggs, the former predominating in the non-malarious districts. The disbursements of the Foundation during the year amounted to $17,477,225$ dollars.

Applications are invited for the following appoint ments, on or before the dates mentioned:-A public analyst for the Metropolitan Borough of Fulham-The Town Clerk, Town Hall, Fulham, S.W.6 (Jan. 4). A principal of the Newport Technical College and Institute-The Director of Education, Education Offices, Charies Street, Newport, Mon. (Jan. 14). A University professor of civil engineering at the Imperial College (City and Guilds College) -The Academic Registrar, University of London, S.W.7 (Feb. 17). 